\title{
FIBRE QUALITY: LENGTH AND SLENDERNESS RATIO OF FIBRE ADJAGENT TO SMALL VESSELS OF ACACIA MANGIUM
}

\author{
Yahya $\mathbf{R}^{1,2, *}$ Yansen $^{1} \&$ Tazuru-Mizuno $S^{2}$ \\ ${ }^{1}$ Faculty of Agriculture, University of Bengkulu, Kota Bengkulu 38371.A, Indonesia \\ ${ }^{2}$ Research Institute for Sustainable Humanosphere, Kyoto University, Uji, Kyoto 611-0011, Japan \\ *ridwanyahya@unib.ac.id
}

Submitted December 2019; accepted April 2020

\begin{abstract}
The purpose of this study was to observe the length and slenderness ratio of fibre based on its distance from a small vessel (diameter 85-109 $\mu \mathrm{m})$. The wood block $10 \mathrm{~mm}$ x $5 \mathrm{~mm}$ x $20 \mathrm{~mm}(\mathrm{R} \times \mathrm{T} \times \mathrm{L})$ was softened, sliced and photographed using a confocal laser scanning microscope. The serial sections were aligned using Reconstruct software. Fibre length was obtained by multiplying section thickness (25 um) by number of cross sections and image J software, respectively, in which the focused wood fibres appeared. The slenderness ratio value was calculated using the formula: fibre length/fibre diameter. Small vessels only caused two adjacent fibres to be shorter and have a smaller slenderness ratio compared to fibres distant from those vessels. Pressure from large vessels caused the five fibres to have a shorter length than the two fibres compressed by small vessels. No statistical difference was found in the slenderness ratio value of fibres adjacent to both large and small vessels, and those distant from large and small vessels, but the two fibres adjacent to the small vessels were significantly longer than the five fibres adjacent to the large vessels.
\end{abstract}

Keywords: Fibre length, fibre diameter, slenderness ratio, small vessels, large vessels

\section{INTRODUCTION}

Wood structure and anatomical characteristics are important considerations for pulp and paper quality (Pirralho et al. 2014, Yahya et al. 2017). Fibre is directly proportional to tear strength and folding endurance (Ona et al. 2001). Fibre dimensions and their derivative values determine the quality of the paper produced (Dutt \& Tyagi 2011). Thin-walled fibres, due to their wide lumens, are easily bonded to other fibres, which consequently increases the strength of the paper produced (Tofanica et al. 2011). Thinwalled fibres also improve the smoothness of the paper surface. The Runkel ratio, coefficient of rigidity, Muhlstep ratio and flexibility coefficient determine the suitability of fibre for paper production (Yahya et al. 2020).

Acacia shows diversity in fibre morphology. This diversity has been shown to vary between and within trees, and between provenances (Nugroho et al. 2012). Diversity also occurs due to biomechanical factors among wood cells (Yahya et al. 2020). The effect occurs due to cell enlargement i.e. extension or increase in cell diameter.

Vessel cells experience the greatest diameter increase in hardwoods such as Acacia mangium.
Radial diameter and wall thickness of fibres adjacent to large vessels $(171-212 \mu \mathrm{m})$ in $A$. mangium, decreased from the first fibre to the fifth fibre, whereas the tangential diameter increased from the first fibre to the fifth fibre (Yahya et al. 2015). The same tendency also occured in the length of fibres adjacent to these vessels-fibre length decreased from the first fibre to the fifth fibre, followed by relatively constant fibre length (Yahya et al. 2011).

Breeding programs in Indonesia are focused on improving pulping qualities of Acacia and fibre properties such as fibre length, Runkel ratio and slenderness ratio as useful indices for plus tree selection, as with vessel proportion and size assessment (Amidon 1981, Ohshima et al. 2011, Nirsatmanto et al. 2015). For A. mangium, where vessels comprise $10.4 \%$, fibres near small vessels (85-109 $\mu \mathrm{m})$ had better Runkel ratios, coefficient of rigidity values and Muhlstep ratios than that of large vessels, indicating that trees with a higher proportion of small vessels may be desirable in breeding for pulp and paper (Yahya et al. 2010, Yahya et al. 2020). The objective of the present study was to determine the length and slenderness ratio of fibres close to small vessels in 
A. mangium, in the context of pulpwood quality evaluation.

\section{MATERIALS AND METHODS}

A wood block of $10 \mathrm{~mm} \times 5 \mathrm{~mm} \times 20 \mathrm{~mm}$ (radial, tangential and longitudinal directions) was cut from near the bark of a seven-year-old $A$. mangium tree. The tree was randomly selected from the trial area of a private forest plantation, Musi Hutan Persada (MHP) Company, South Sumatra, Indonesia. The sample was prepared following the method described in Yahya et al. (2020), as briefed below.

The wood block was first softened by autoclaving with alcohol and glycerol (1:1 ratio). Then it was serially sectioned into 200 pieces of $25 \mu \mathrm{m}$-thick cross-sections that were then sequentially mounted on glass slides. Photographs were taken of the sections, viewed through a confocal laser scanning microscope. The Reconstruct software was applied for alignment (Fiala 2005). The serial section images and image $J$ software were used to examine the aligned images in 3D.

In this study, the length and radial diameters of fibres adjacent to small vessels (lumen diameter 85-109 $\mu \mathrm{m}$ ) were measured. Total fibres measured were 178. Fibre length was obtained by multiplying section thickness $(25 \mu \mathrm{m})$ with number of cross sections in which the fibre appeared (Attachment 1). Slenderness ratio was calculated by dividing fibre length with fibre diameter.

Mann-Whitney and t-tests were used to compare length and slenderness ratio between fibre, based on their distance from small vessels (recorded in the present study) and big vessels (Yahya et al. 2011).

\section{RESULTS AND DISCUSSION}

\section{Variation in fibre length}

Variation in the fibre length occurred as the distance from the vessel changed. Figure 1 shows that in the radial direction, average fibre length increased from $700 \mu \mathrm{m}$ for the $1^{\text {st }}$ fibre from the small vessel to $1061 \mu \mathrm{m}$ for the $3^{\text {rd }}$ fibre from the small vessel, and then was relatively constant up to the $13^{\text {th }}$ fibre from the small vessel. For fibres adjacent to large vessels, average fibre length increased from $610 \mu \mathrm{m}$ for the $1^{\text {st }}$ fibre from the vessel to $920 \mu \mathrm{m}$ for the $6^{\text {th }}$ fibre from the vessel, and then was relatively constant $(1075 \mu \mathrm{m})$ up to the $10^{\text {th }}$ fibre from the vessel (Yahya et al. 2011).

Fibre length of $A$. mangium near the pith was 1040 to $1080 \mu \mathrm{m}$ (Nurgoho et al. 2012). In this study, the measured fibres were mostly distant from the vessels. The length of fibre distant from the vessel was relatively the same as the fibre length in the previous study (Nurgoho et al. 2012).

It was assumed that the initial fusiform or xylem mother cells in the cambial zone formed about two fibres in the radial direction, and it was hypothesized that the length of fibres is affected by vessel maturation. The processes that occur during differentiation determine fibre dimensions (Ridoutt \& Sands 1993, Rao et al. 2011). State of maturation of other nearby xylem elements affect the final dimensions of wood fibres (Honjo et al. 2006).

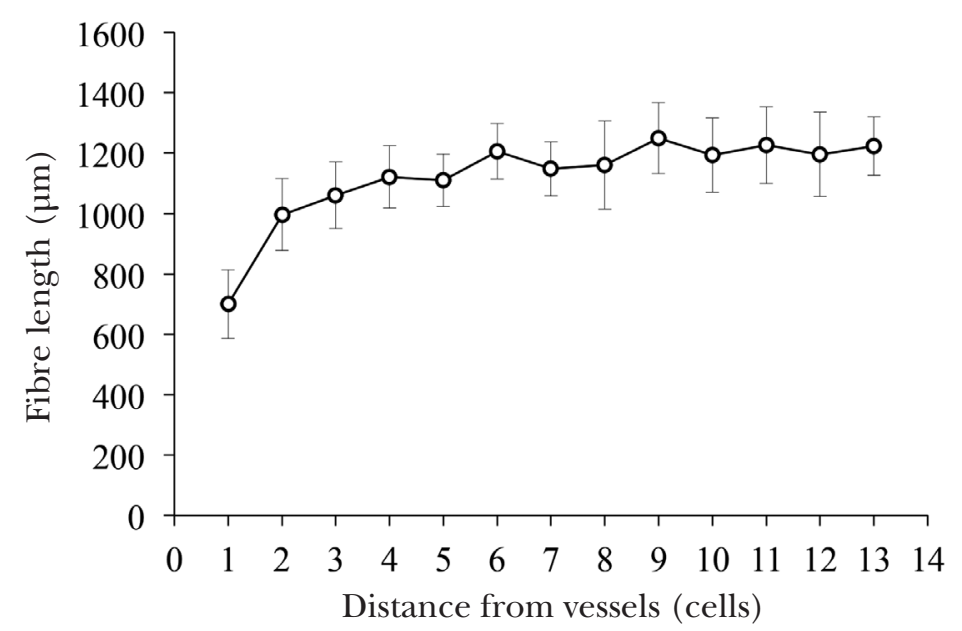

Figure 1 Mean fibre length ( \pm standard deviation) in relation to distance from small vessels of Acacia mangium 
Vessel-adjacent fibres decreased in length, similar to previous research findings (Yahya et al. 2011). There are differences between fibres adjacent to vessels classified as small vessels (85$109 \mu \mathrm{m})$ in the present study, and fibres adjacent to vessels classified as large vessels (171 -212 $\mu \mathrm{m})$ in the previous study. Fibres close to large vessels are shortened to the fifth fibre of the vessel (Yahya et al. 2011), while those close to small vessels were only up to the second fibre.

The Mann-Whitney and t-test results in Table 1 show that the average length of fibres adjacent to small vessels $(859 \mu \mathrm{m})$ was significantly greater large vessels $(642 \mu \mathrm{m})$. However, there was no statistically significant difference in fibre length between those far from large vessels $(1075 \mu \mathrm{m})$ and small vessels $(1191 \mu \mathrm{m})$.

\section{Quality of fibres based on their distance from small and large vessels}

Fibres adjacent to both small and large vessels were significantly shorter than fibres far from the vessels (Table 1). There was no significant difference in length of fibres far from both small and large vessels, indicating that the pressure exerted on fibres by the vessels (both small and large) only affected adjacent fibres.

The results indicated that pressure from a large vessel resulted in the shortening of five fibres, which were shorter on average than the two fibres compressed by a small vessel. The average length of the first two fibres near a small vessel was $859 \mu \mathrm{m}, 28 \%$ shorter than that of the more distant fibres $(1191 \mu \mathrm{m})$. Table 1 shows that fibres adjacent to large vessels have a mean length of $642 \mu \mathrm{m}, 40 \%$ shorter than the more distant fibres $(1075 \mu \mathrm{m})$, indicating that the reduction in length of fibres adjacent to small vessels was smaller than large vessels. Therefore the number of shortened fibres correlated with vessel size, while the length of shortened fibres negatively correlated with vessel size. Wood that contains longer fibres will produce stronger paper, because fibre length is positively correlated with burst strength, tensile strength, tear strength and folding endurance (Ona et al. 2001, Kiaei et al. 2014, Pirralho et al. 2014).

Variation in slenderness ratio occurred as the distance from the vessel changed. Figure 2 shows that in the radial direction, average slenderness ratio increased from 25 in the $1^{\text {st }}$ fibre from the vessel to 52 in the $3^{\text {rd }}$ fibre from the small vessel, and then was relatively constant up to the $13^{\text {th }}$ fibre from the vessel.

Slenderness ratio of fibres distant from vessels in the present study was relatively the same as the previous study. The average slenderness ratio of A. mangium was 54 (Jusoh et al. 2014) and 51.29 (Yahya et al. 2010).

The slenderness ratio of the two fibres adjacent to the small vessels was smaller than that of distant fibres. Likewise, the five fibres adjacent to the large vessels was smaller than that of distant fibres (Table 1). There was no significant difference between fibres that were far from large and small vessels. Fibres adjacent to large and small vessels did not show significant differences in slenderness ratio values (Table 1).

Fibre length and slenderness ratio are directly proportional to the strength of the fibre (Shakhes et al. 2011). Slenderness ratio determines the bonding ability of individual fibres (Omotoso \& Owolabi 2015). Fibres with high slenderness ratio

Table 1 Mean fibre length ( \pm standard deviation) and slenderness ratio of in relation to radial distance from small and large vessels of Acacia mangium

\begin{tabular}{|c|c|c|c|}
\hline 1. & Distance from vessel & Fibre length $(\mu \mathrm{m})$ & Slenderness ratio \\
\hline & $\begin{array}{l}5 \text { fibres to large vessel }{ }^{1)} \\
6-10 \text { fibres from large vessel }{ }^{1)}\end{array}$ & $\begin{array}{r}642 * * \\
1075\end{array}$ & $\begin{array}{r}33^{*} \\
54.8\end{array}$ \\
\hline 2. & $\begin{array}{l}2 \text { fibres to small vessel } \\
3-13 \text { fibres from small vessel }\end{array}$ & $\begin{array}{r}859 * * \\
1191\end{array}$ & $\begin{array}{r}34 * * \\
60\end{array}$ \\
\hline 3. & $\begin{array}{l}5 \text { fibres to large vessel }{ }^{1)} \\
2 \text { fibres to small vessel }\end{array}$ & $\begin{array}{r}642 * * \\
859\end{array}$ & $\begin{array}{r}33^{\text {ns }} \\
34\end{array}$ \\
\hline 4. & $\begin{array}{l}\text { 6-10 fibres from large vessel }{ }^{1)} \\
3-13 \text { fibres from small vessel }\end{array}$ & $\begin{array}{r}1075^{\mathrm{ns}} \\
1191\end{array}$ & $\begin{array}{r}54.8^{\text {ns }} \\
60\end{array}$ \\
\hline
\end{tabular}

$* *=$ significantly different at the 0.01 level, $*=$ at the 0.05 level; ns $=$ non significant, ${ }^{1)}$ Yahya et al. (2011) 


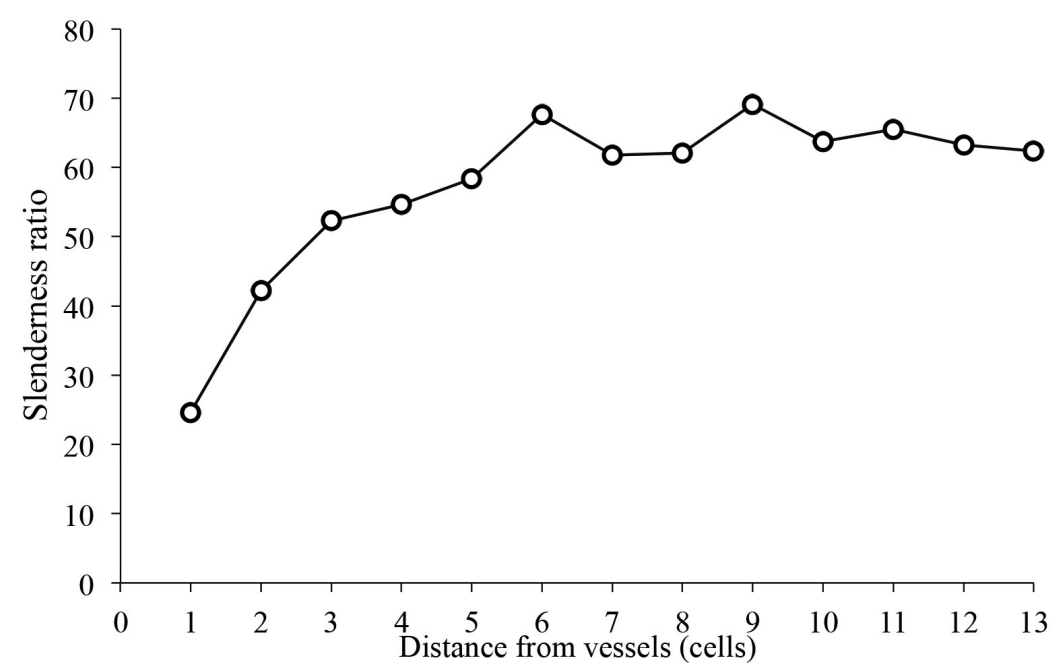

Figure 2 Mean slenderness ratio in relation to distance from small vessels of Acacia mangium

will greatly help fibres to collapse and form interfibre bonding during the formation of paper. The stronger the inter-fibre bond between fibres, the higher the tensile strength, bursting strength and folding endurance of the paper produced.

The results of the study concured with the previous study which showed that dimension and derivative values such as diameter, wall thickness, Runkel Ratio, coefficient of rigidity, Muhlstep ratio and flexibility coefficient values of fibres adjacent to small vessels were better suited as raw material for paper than fibres adjacent to large vessels (Yahya et al. 2020). Wood with small diameter vessels is preferable for paper production (Takeuchi et al. 2016). Thus, the study recommended the breeding of $A$. mangium of smaller vessel size to produce good quality fibre as a raw material for paper industry.

\section{CONGLUSIONS}

Small vessels caused two adjacent fibres to be shorter compared to fibres distant from the vessel. The two fibres adjacent to small vessels were significantly longer than the five fibres adjacent to large vessels. No statistical differences were found between the lengths of the fibres that were distant from large vessels and small vessels.

There were five fibres adjacent to large vessels that had smaller slenderness ratio value than those distant from the vessels, but only two fibres had smaller slenderness ratio value, close to small vessels. No statistical differences were found between slenderness ratio value of fibre, both adjacent to large and small vessels, and those far from large and small vessels.

\section{ACKNOWLEDGMENTS}

The study was funded by the Ministry of Research, Technology and Higher Education, Indonesia. The authors would like to thank Dr. T. Imai (RISH, Kyoto University) for laser scanning microscopy and data preparation with Reconstruct software.

\section{REFERENCES}

Amidon TE. 1981. Effect of the wood properties of hardwoods on kraft paper properties. Tappi Journal 64: 123-126.

DutT D \& Tyagi CH. 2011. Comparison of various eucalyptus species for their morphological, chemical, pulp and paper making characteristics. Indian Journal of Chemical Technology 18: 145-151.

FialA J. 2005. Reconstruct: A free editor for serial section microscopy. Journal of Microscopy 218: 52-61. doi. org/10.1111/j.1365-2818.2005.01466.x

Honjo K, Ogata Y \& Fujita M. 2006. Introduction and verification of a novel method for measuring wood fibre length using a single cross-section in Acacia mangium. Trees 20: 356-362. doi.org/10.1007/s00468005-0048-9

Jusoh I, Zaharin FA \& Adam NS. 2014. Wood quality of Acacia hybrid and second-generation Acacia mangium. BioResources 9: 150-160. doi.org/10.15376/ biores.9.1.150-160

Kiaei M, Mahdavi S, Kialashaki A, Nemati M, Samariha A \& Saghafi A. 2014. Chemical composition and morphological properties of canola plant and its potential application in pulp and paper industry. Cellulose Chemistry and Technology 48: 105-110. 
Nirsatmanto A , Setyaji T, Sunarti S \& Kartikaningtyas D. 2015. Genetic gain and projected increase in stand volume from two cycles breeding program of Acacia mangium. Indonesian Journal of Forestry Research 2: 7179. doi.org/10.20886/ijfr.2015.2.2.71-79

Nugroho WD, Marsoem SN, Yasue K et AL. 2012. Radial variations in the anatomical characteristics and density of the wood of Acacia mangium of five different provenances in Indonesia. Journal of Wood Science 58: 185-194. doi.org/10.1007/s10086-0111236-4

Ohshima J, Yокота S, Yoshizawa N \& Ona T. 2011. Feasibility study of quality plantation pulpwood breeding on fibre length, vessel element length and their ratio sought by within-tree variations in Eucalyptus trees. Forestry Studies 54: 37-47. DOI: 10.2478/v10132-0110094-6

Омотоso A \& Owolabi AW. 2015. Pulp and paper evaluation of solid wastes from agricultural produce. International Journal of Chemistry 7: 113-121. doi.org/10.5539/ijc. v7n2p113

Ona T, Sonoda T, Ito K et AL. 2001. Investigation of relationship between cell and pulp properties in Eucalyptus by examination of within-tree property variations. Wood Science and Technology 35: 363-375.

Pirralho M, Flores D, Sousa VB, Quilhó T, Knapic S \& Pereira H. 2014. Evaluation on paper making potential of nine Eucalyptus species based on wood anatomical features. Industrial Crops and Products 54: 327-334. doi.org/10.1016/j.indcrop.2014.01.040

RAO KS, Kim JS \& KIm YS. 2011. Early changes in the radial walls of storied fusiform cambial cells during fibre differrentiation. IAWA Journal 32: 333-340. doi. org/10.1163/22941932-90000061

RidoutT BG \& SANDS R. 1993. Within-tree variation in cambial anatomy and xylem cell differentiation in Eucalyptus globulus. Trees 8: 18-22. doi.org/10.1007/ BF00240977
Shakhes J. Zeinaly F, Marandi MAB \& Saghafi T. 2011. The effect of processing variables on soda and soda-aq pulping of kenaf bast fibre. Bioresources 6: 4626-4639.

TAKeuchi R, Wahyudi I, Aiso H et AL. 2016. Wood properties related to pulp and paper quality in two Macaranga species naturally regenerated in secondary forests, Central Kalimantan, Indonesia. Tropics 25:107-115. DOI: 10.3759/tropics.MS15-23

Tofanica BM, Cappelletto E, Gavrilescu D \& Mueller K. 2011. Properties of rapeseed (Brassica napus) stalks fibres. Journal of Natural Fibres 8: 241-262. DOI: 10.1080/15440478.2011.626189.

Yahya R, Sundaryono A, Imai T \& Sugiyama J. 2015. Distance from vessels changes fibre morphology in Acacia mangium. IAWA Journal 36: 36-43. doi. org/10.1163/22941932-00000083

Yahya R, Koze K \& Sugryama J. 2011. Fibre length in relation to the distance from vessels and contact with rays in Acacia mangium. IAWA Journal 32: 341-350. doi. org / 10.1163/22941932-90000062

Yahya R, SugiYama J, Silsia D \& GriL J. 2010. Some anatomical features of an Acacia hybrid, A. mangium and A. auriculiformis grown in Indonesia with regard to pulp yield and paper strength. Journal of Tropical Forest Science 22: 343-351.

Yahya R, Yansen Y, Sundaryono A, Horikawa Y \& Sugiyama J. 2017. Neighborhood of vessels: Chemical composition and microfibril angle of fibre within Acacia mangium. Journal of Tropical Forest Science 29: 267-274. doi.org/10.26525/jtfs2017.29.3.267274

Yahya R, Yansen Y, Tazuru-Mizuno S \& Sugiyama J. 2020. Effect of vessel diameter on variation of fibre morphology in Acacia mangium. IAWA Journal 41: 1-10. doi.org/10.1163/22941932-00002100 

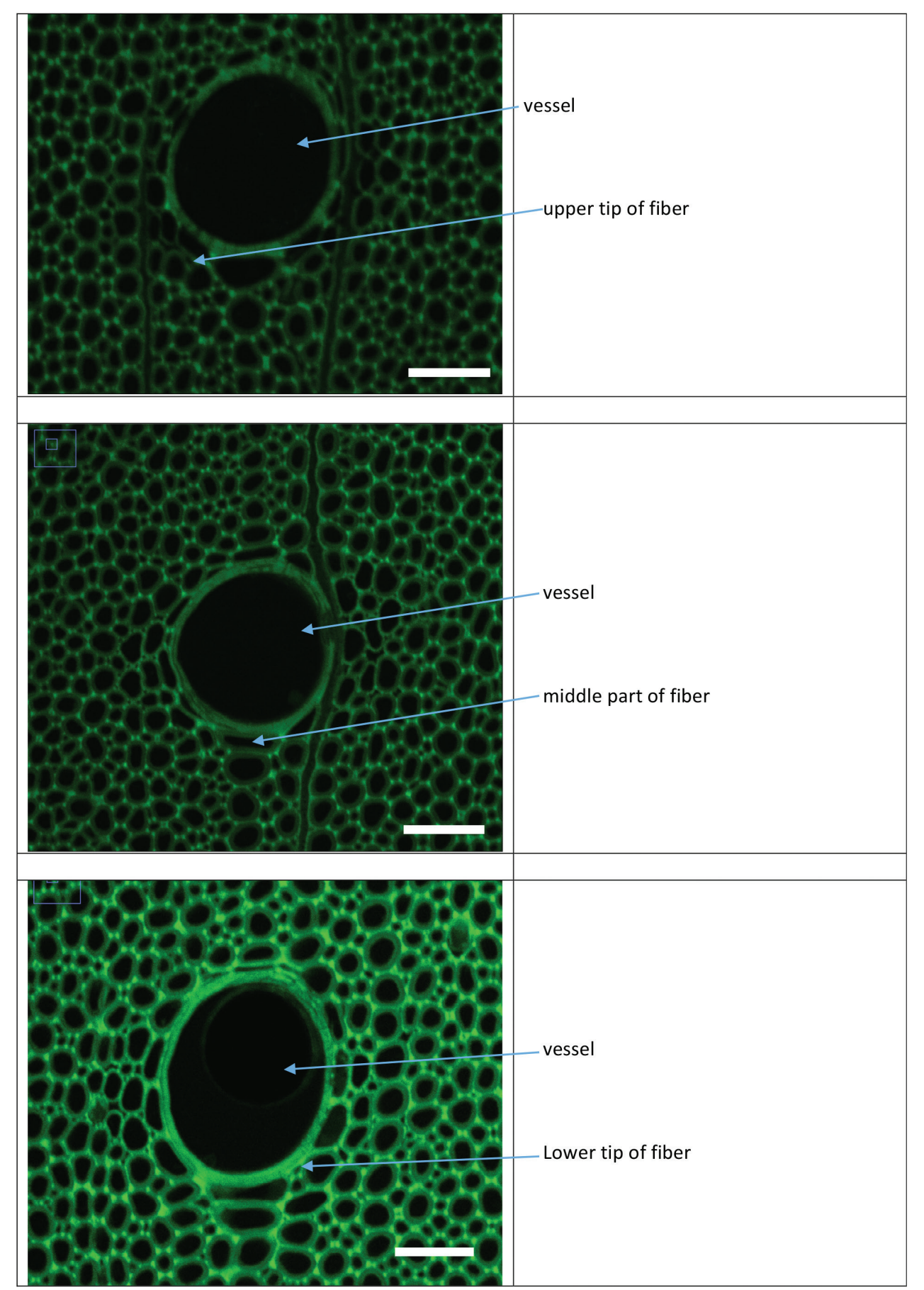

Attachment 1 Fibre length tracing using 3D serial cross section; scale bar $=50 \mu \mathrm{m}$ 